\title{
Association between early pregnant hospitalization and use of obstetric interventions and cesarean: a cross-sectional study
}

\author{
Associação entre internação precoce de gestantes e uso de intervenções obstétricas e cesarianas: estudo transversal
}

Relación entre internación precoz de embarazadas y uso de intervenciones obstétrica y cesarianas: estudio transversal

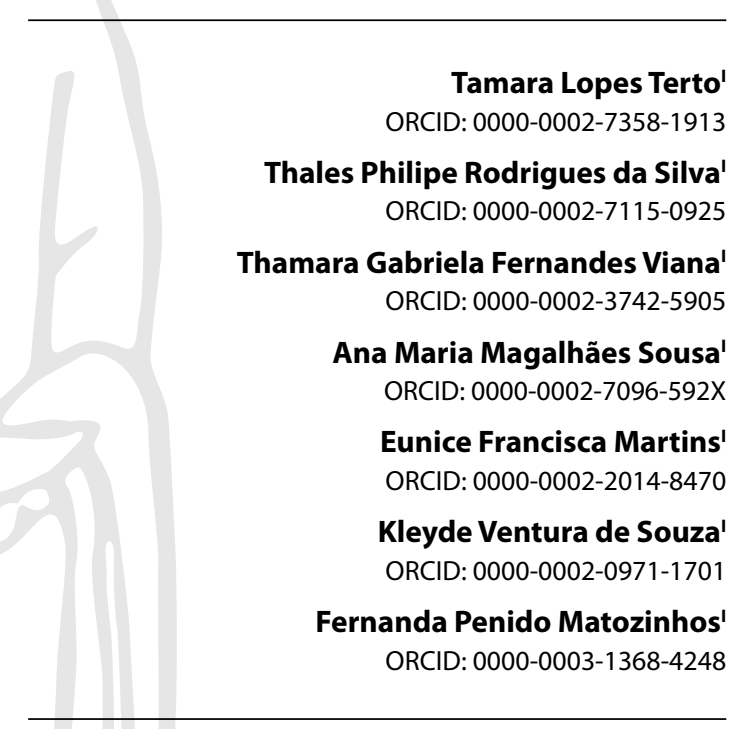

'Universidade Federal de Minas Gerais. Belo Horizonte, Minas Gerais, Brazil.

How to cite this article: Terto RL, Silva TPR, Viana TGF, Sousa AMM, Martins EF, Souza KV, et al. Association between early pregnant hospitalization and use of obstetric interventions and cesarean: a crosssectional study. Rev Bras Enferm. 2021;74(4):e20200397. https://doi.org/10.1590/0034-7167-2020-0397

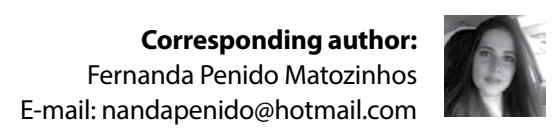

EDITOR IN CHIEF: Antonio José de Almeida Filho ASSOCIATE EDITOR: Ana Fátima Fernandes

Submission: 07-01-2020 Approval: 10-05-2020

\begin{abstract}
Objective: Evaluate the association between early pregnant hospitalization and the use of obstetric interventions and cesarean delivery route. Methods: Cross-sectional study, with 758 women selected at the time of childbirth. It was assumed as early hospitalization when the woman was admitted to the hospital having less than $6 \mathrm{~cm}$ of cervical dilation. Logistic regression models were constructed in order to estimate the odds ratio for each obstetric intervention, adjusted by sociodemographic and obstetric variables. Results: $73.22 \%$ of women were early hospitalized. On average, they had 1.97 times the chance to undergo Kristeller's maneuver, 2.59 and 1.80 times the chance to receive oxytocin infusion and analgesia, respectively, and 8 times more chances to having their children by cesarean delivery when compared to women that had timely hospitalization. Conclusion: Early hospitalized women were submitted to a higher number of obstetric intervention and had increased chances of undergoing cesarean sections.

Descriptors: Obstetric Nursing; Perinatal Care; Childbirth; Labor, Obstetric; Clinical Protocols.
\end{abstract}

\section{RESUMO}

Objetivo: Avaliar a associação entre a internação precoce de gestantes e o uso de intervenções obstétricas e via de nascimento cesariana. Métodos: Estudo transversal, com 758 mulheres selecionadas por ocasião da realização de parto. Assumiu-se como internação precoce quando a mulher foi admitida no hospital tendo menos que $6 \mathrm{~cm}$ de dilatação cervical. Foram construídos modelos de regressão logística para estimar a odds ratio para cada intervenção obstétrica, ajustados pelas variáveis sociodemográficas e obstétricas. Resultados: Das mulheres, $73,22 \%$ foram internadas precocemente. Em média, estas tiveram 1,97 vezes a chance de sofrerem a manobra de Kristeller, 2,59 e 1,80 vezes a chance de receberem a infusão de ocitocina e analgesia, respectivamente, e 8 vezes mais chances de terem seus filhos por cesariana quando comparadas às mulheres que tiveram a internação oportuna. Conclusão: Mulheres internadas precocemente foram submetidas a um maior número de intervenção obstétrica e tiveram chances aumentadas de sofrerem cesarianas.

Descritores: Enfermagem Obstétrica; Assistência Perinatal; Parto; Trabalho de Parto; Protocolos Clínicos.

\section{RESUMEN}

Objetivo: Evaluar relación entre internación precoz de embarazadas y uso de intervenciones obstétricas y vía de nacimiento cesariana. Métodos: Estudio transversal, con 758 mujeres seleccionadas por ocasión de realización de parto. Se asumió como internación precoz cuando la mujer ha sido admitida en hospital teniendo menos que $6 \mathrm{~cm}$ de dilatación cervical. Han construidos modelos de regresión logística para estimar la odds ratio para cada intervención obstétrica, ajustados por variables sociodemográficas y obstétricas. Resultados: De las mujeres, $73,22 \%$ se internaron precozmente. En media, estas tuvieron 1,97 veces la chance de sufrieren la maniobra de Kristeller, 2,59 y 1,80 veces la chance de recibir la infusión de oxitocina y analgesia, respectivamente, y 8 veces más chances de tener sus hijos por cesariana cuando comparadas a las mujeres que tuvieron internación oportuna. Conclusión: Mujeres internadas precozmente se someten a un mayor número de intervención obstétrica y tuvieron chances aumentadas de sufrir cesarianas.

Descriptores: Enfermería Obstétrica; Asistencia Perinatal; Parto; Trabajo de Parto; Protocolos Clínicos. 


\section{INTRODUCTION}

In recent years, the prevalence of births by cesarean delivery have increased in the world ${ }^{(1)}$. In the United States, around 33\% of women undergo surgeries ${ }^{(2)}$. In Brazil, a nationwide study from the early 2010 s showed that cesarean rates varied from $87.9 \%$ in private sector to $42.9 \%$ in public sector ${ }^{(3)}$. It should be noticed that the World Health Organization (WHO), in 1985 and later in 2015 , pointed that cesarean delivery is an effective alternative to decrease the mother death and perinatal taxes when there is real indication. However, cesarean delivery taxes over $10 \%$ do not decrease such negative outcomes ${ }^{(4)}$.

Given the expressive number of cesarean deliveries, authors discuss the moment considered safer to hospitalization of the woman ${ }^{(5)}$. In Brazil, the definition of normal progression of first stage labor is based on data published in the 1950s. Friedman's(6) study consider that the latent phase of labor comprise from 0-4 centimeters $(\mathrm{cm})$ of cervical dilation; and the active stage, from 4 to $10 \mathrm{~cm}$, opportune moment for the parturient woman's hospitalization $^{(6)}$.

In 2010, data from 60 thousand women from the United States provided estimates for the building of a modern labor progression curve, which consider for admission, a value of $6 \mathrm{~cm}$ of Cervical Dilation (CD), and shows that early hospitalization is associated to a higher risk of unnecessary interventions ${ }^{(5)}$, such as cesarean deliveries, greater infusion of oxytocin and epidural, increased episiotomy rate, regardless the parturient woman's hospitalization $^{(7-8)}$.

American College of Obstetricians and Gynecologists (ACOG) and Society for Maternal-Fetal Medicine (SMFM) guidelines established that, in order to decrease cesarean delivery taxes, it should be used the value of $6 \mathrm{~cm}$ of $C D$ as a parameter to start the active phase of labor ${ }^{(9)}$. Scientific evidences show that several practices in labor assistance, such as timely hospitalization, are crucial for better obstetric results and undoubtedly contributes for the decrease of negative perinatal outcomes.

Given the above, scientific evidence culminated in the development of recommendations about care patterns related to labor and birth, denominated "Good practices in childbirth care". These evidences were used as a basis for the creation of National Guidelines for Assistance of Normal Childbirth, developed by the Ministry of Health (MH) and partner institutions, aiming the provision of subsidies and guidance to all those involved in the care, in order to promote, protect and encourage vaginal delivery ${ }^{(10)}$.

Considering the persistence of high rates of interventions without indications based on scientific evidences, this study presents the hypothesis that the early hospitalization (before 6 $\mathrm{cm}$ of cervical dilation) elevates the use of obstetric interventions (OI) and the occurrence of unnecessary cesarean deliveries. The results obtained should subside health actions aimed at improving delivery and birth care practices.

\section{OBJECTIVE}

Evaluate the association between early pregnant hospitalization and the use of obstetric interventions and cesarean delivery route.

\section{METHODS}

\section{Ethical aspects}

The present study was approved by the had the Ethics Committee of the Federal University of Minas Gerais, as well as by the heads of the maternity hospitals involved, and all women interviewed recently signed the Free Informed Consent Form.

\section{Design, place of study and period}

This is an observational study, with cross-sectional design guided by the STROBE tool, and developed based on the data from the survey "Born in Belo Horizonte: Survey on childbirth and birth", held in 11 maternity hospitals in Belo Horizonte, State of Minas Gerais, 7 of them with public service, and 4 with private service.

Data collection was done by means of interviews performed by nurses trained by the Project coordinating teams, carried out with the mothers through the application of a structured research instrument, at least six hours after labor, in the period of November 2011 to March 2013. In addition, mother's medical records data was used. More information about the sample design are detailed in another publication ${ }^{(11)}$.

\section{Sample}

For sample calculation, the number of childbirths performed in each participant maternity that had 500 or more born alive in 2007 was used, according to the Born Alive Information System (SINASC). The sample process had three stages: selection of participant hospitals, reverse sampling method, and random selection of mothers.

For this study, all the pregnant admitted in the selected maternities on childbirth, and those who had the CD information by evaluated by a professional at the moment of the admission registered in their medical records were considered eligible. The final sample had 758 mothers, of a total of 1,088.

\section{Study protocol}

As the main explanatory variable, early hospitalization was considered the moment when the women were admitted at the hospital with less than $6 \mathrm{~cm}$ of CD in active stage of labor, given that: $0-C D \geq 6 \mathrm{~cm}$; and $1-\mathrm{DC}<6 \mathrm{~cm}$.

The outcomes of this study were obstetric interventions (Ols) and delivery route (vaginal or cesarean). Ols were based on the recommendations regarding care patterns in normal birth, proposed by WHO in 1996 and, subsequently, ratified by the Ministry of Health and called "Good practices in the care of normal birth"(12). They are: demonstrably useful practices that should be stimulated; clearly harmful or ineffective practices that must be eliminated ("lying on your back with legs raised" position" and Kristeller' maneuver), and practices frequently used inappropriately during labor and childbirth (amniotomy, oxytocin infusion, analgesia and episiotomy) ${ }^{(12)}$.

Other variables included in this survey refer to sociodemographic characteristics (age, color, paid employment, education, and presence of a partner), obstetric/pregnancy history (companion during hospitalization, gestational age, number of prenatal consultations, primiparity), clinics, delivery route, in addition to 


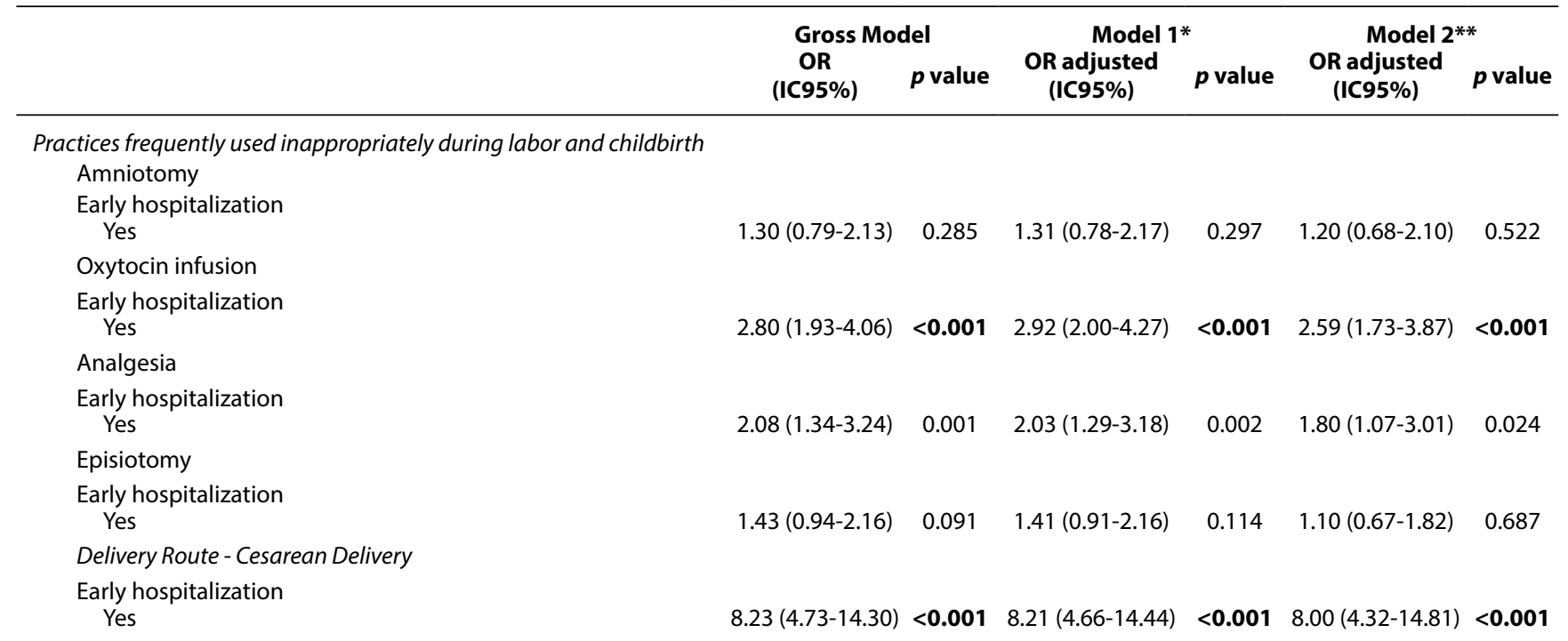

Notes: Values in bold $=p<0.05 ;$ OR $=$ odds ratio; IC95\% = confidence interval of $95 \% .{ }^{*}$ Model adjusted by sociodemographic variables (age, education, marital status, color, and paid employment), **Model adjusted by variables present in Model 1 plus obstetric and assistance variables (companion during hospitalization, gestational age, number of prenatal consultations, primiparity, presence of an obstetric nurse at the institution, clinical or obstetric complications and hospital financing); In all models with significance for early hospitalization, the $p$ value in Hosmer-Lemeshow method for the Model 2 was higher than 0.05 .

\section{DISCUSSION}

The results of this study showed a significant association between the early hospitalization and the obstetric practices (Kristeller' maneuver, oxytocin infusion, and analgesia), in addition to the influence of cesarean delivery route.

Proper managing during the labor latent stage has the objective that the parturient woman's hospitalization is performed in a timely manner, which contributes to lower risks of interventions and, then, decrease the number of negative outcomes during the labor and childbirth. For timely hospitalization, it would be appropriate for the pregnant woman to be guided, received, supported and receive care and orientations based on good practices in childbirth and birth care ${ }^{(10,12)}$, based on quaternary prevention $^{(13)}$. In addition, an urgent change in Brazilian obstetric scenario is necessary, overcoming the technocratic model and its resulting hypermedicalization, in order to qualify childbirth care by aligning the use of evidence-based practices in childbirth to women-centered care ${ }^{(13)}$. Doubtless, this is one of the most evident contributions of obstetric nursing.

Interventionist attention culminates with high taxes of cesarean delivery, and Brazil is worldly recognized for this negative rate. Early hospitalization, as highlighted in this study, increases the chances of cesarean delivery without justification and non-based on scientific evidence. Observational studies have also shown a relation between increased rates of cesarean sections in women who had early admission to labor ${ }^{(8,14-15)}$. Another possible relation shown by International studies is that parturient women hospitalized in the latent phase receive a higher number of unnecessary interventions, highlighting the oxytocin infusion and ${ }^{(16)}$, which contributes to increase the cesarean delivery rate (7-8,16-17). $^{(1)}$

It should be noted that the interventions do not occur in isolation, since the oxytocin infusion and were increased in this study, with a higher probability of occurrences in women admitted in latent stage of labor. International studies bring similar findings, and such interventions are statistically related to delivery route ${ }^{(8,18-20)}$. It was also possible to evaluate that parturient women submitted to analgesia during labor present an increased chance of being subjected to oxytocin infusion ${ }^{(21)}$.

The early hospitalization, associated to cesarean delivery, contributes to negative outcomes, resulting from the unnecessary performance of this procedure. Such surgeries, when indicated without a precise indication, are associated with increased maternal and neonatal morbidity and mortality and lead to longer hospital stays, greater chance of puerperal infection, maternal hemorrhage, delayed peridural analgesia postpartum recovery time, late breastfeeding, prematurity and increased spending on the health system ${ }^{(22-23)}$.

Research conducted with the survey"Born in Brazil: a survey on childbirth and birth"about the use of obstetric interventions during childbirth and labor in pregnant women with usual risk showed high rate of obstetric interventions, revealing that, in large part, interventions were unnecessary ${ }^{(18)}$.

In order to identify necessary obstetric interventions during labor, WHO has proposed, since $1994^{(24)}$, the use of the partogram, that is the graphic representation of childbirth. Recently, newWHO guidelines regarding intrapartum care for a positive childbirth experience recognize that each childbirth is unique and the duration of the first stage of labor can vary in each woman ${ }^{(25)}$. Thus, interventions to accelerate childbirth are not recommended, such as the oxytocin infusion or cesarean delivery before $5 \mathrm{~cm}$ of $\mathrm{CD}^{(25)}$. The results of this survey also corroborates of a National survey, which indicates the use of oxytocin indiscriminately ${ }^{(18)}$.

Kristeller's maneuver, another unappropriated intervention, due to inefficiency and deleterious effects to women and to the babies ${ }^{(26)}$, is still performed in around $36 \%$ of the parturient women in the country ${ }^{(18)}$. In this study, it was evidenced with a double chance of occurrence in women admitted in the latent phase of childbirth. Such unappropriated interventions and mistakenly used during labor contribute in violating women's right, causing, among other aspects, discomfort for the parturient women. Kristeller's maneuver is classified as one of the numerous possibilities of obstetric violence that parturient woman may suffer. 
Findings of this study point to a technocratic obstetric model, in which obstetric interventions are used in unappropriated way, which may result damages to the mother and the newborn. Assistance during labor provides for the work of the multidisciplinary team to avoid the use of unnecessary interventions and to guide the pregnant women about specifics of this moment. It is also evident that the rates of obstetric interventions may be related to the professional conducting labor, being lower when they are nurses ${ }^{(27-28)}$, specially obstetric nurses. In addition to less interventionist care, the performance of obstetric nursing, through its training, seeks to rescue the leadership of women during labor ${ }^{(29)}$. Together with other members of multidisciplinary team, these professionals recognize the parturition process as physiological and work providing guarantee of rights, safety, and comfort to women during labor, childbirth, and post childbirth ${ }^{(30)}$.

\section{Study limitations}

As this is a cross-sectional study, it was not possible to identify the temporality associations shown here. Furthermore, as it was used a medical record to collect information, some information may be lost for certain variables.

\section{Contributions to Nursing area}

Despite these limitations, this study advances in the perspective of data analysis still not totally explored in the area of obstetric nursing, for its contribution to reorganization of services, processes and care practices management, in addition to the potential contribution to changing the model of care for childbirth and birth. The results can serve as a basis for better assistance and safer and less technocratic care at birth, replacing the excess of obstetric interventions.

\section{CONCLUSION}

The findings of this survey emphasize that women early hospitalized were submitted to a higher number of obstetric interventions and had increased chances of undergoing cesarean section. It is noticed that obstetric care practices are still based on the technocratic care model.

Such results indicate the need to effectuate public policies in women health field and obstetric attention in the country, aiming the adoption of more assertive practices during prenatal care and childbirth. This is a complex task, which passes by professional qualification (that produces interference in work processes, in the multi/interprofessional team and in integrated/people-centered care, supported by the best scientific evidence); by the relations among professionals, users and their families; by health system management and reorganization of process and care practices; by social participation (including women when deciding about their lives and their bodies); and, still, for the issues related to the commercialization of the care to the birth.

\section{REFERENCES}

1. Betrán AP, Ye J, Moller A-B, Zhang J, Gülmezoglu AM, Torloni MR. The increasing trend in caesarean section rates: global, regional and national estimates: 1990-2014. PLoS One. 2016;11(2):e0148343. https://doi.org/10.1371/journal.pone.0148343

2. Batista Filho M, Rissin A. A OMS e a epidemia de cesarianas. Rev Bras Saúde Matern Infant. 2018;18(1):5-6. https://doi. org/10.1590/1806-93042018000100001

3. Nakamura-Pereira M, Carmo Leal M, Esteves-Pereira AP, Domingues RMSM, Torres JA, Dias MAB, et al. Use of Robson classification to assess cesarean section rate in Brazil: the role of source of payment for childbirth. Reprod Health. 2016;13:(Suppl 3). https://doi.org/ 10.1186/ s12978-016-0228-7

4. Organização Mundial de Saúde (OMS). Departamento de Saúde Reprodutiva e Pesquisa. Programa de Reprodução Humana. Declaração da OMS sobre Taxas de Cesáreas. Genebra: OMS [Internet]. 2015 [cited 21 May 2020]. Available from: http://apps.who.int/iris/bitstream/ handle/10665/161442/WHO_RHR_15.02_por.pdf?sequence=3

5. Zhang J, Landy HJ, Ware Branch D, Burkman R, Haberman S, Gregory KD, et al. Contemporary patterns of spontaneous labor with normal neonatal outcomes. Obstet Gynecol. 2010;116(6):1281-7. https://doi.org/10.1097/AOG.0b013e3181fdef6e

6. Friedman EA. The graphic analysis of labor. Am J Obs Gynecol. 1954;68(6):1568-75. https://doi.org/10.1016/0002-9378(54)90311-7

7. Abasian Kasegari F, Pazandeh F, Darvish S, Huss R, Nasiri M. Admitting women in active labour: a randomised controlled trial about the effects of protocol use on childbirth method and interventions. Women Birth. 2019;S1871-5192(19):30894-7. https://doi.org/10.1016/j. wombi.2019.12.002

8. Rota A, Antolini L, Colciago E, Nespoli A, Borrelli SE, Fumagalli S. Timing of hospital admission in labour: latent versus active phase, mode of birth and intrapartum interventions, a correlational study. Women Birth. 2018;31(4):313-8. https://doi.org/10.1016/j.wombi.2017.10.001

9. Cohen WR, Friedman EA. Perils of the new labor management guidelines. Am J Obstet Gynecol. 2015;212(4):420-7. https://doi.org/10.1016/j. ajog.2014.09.008

10. Ministério da Saúde (BR). Secretaria de Ciência, Tecnologia e Insumos Estratégicos. Departamento de Gestão e Incorporação de Tecnologias em Saúde. Diretrizes Nacionais de Assistência ao Parto Normal. Brasília: Ministério da Saúde [Internet]. 2017[cited 15 Aug 2020]. Available from:https://portaldeboaspraticas.iff.fiocruz.br/wp-content/uploads/2018/07/diretrizes_nacionais_assistencia_parto_normal.pdf11

11. Vasconcellos MTL, Silva PLN, Pereira APE, Schilithz AOC, Souza Jr PRB, Szwarcwald CL. Sampling design for the Birth in Brazil: national survey into labor and birth. Cad Saude Publica. 2014;30(Suppl1):49-58. https://doi.org/10.1590/0102-311X00176013 
12. World Health Organization (WHO). Care in normal birth: a practical guide. Technical Working Group, World Health Organization. Birth[Internet]. 1997[cited 15 Aug 2020];24(2):121-3. Available from: http://www.ncbi.nlm.nih.gov/pubmed/9271979

13. Souza JP, Pileggi-Castro C. Sobre o parto e o nascer: a importância da prevenção quaternária. Cad Saúde Pública. 2014;30(Suppl-1):S11-3. https://doi.org/10.1590/0102-311XPE02S114

14. Davey MA, McLachlan HL, Forster D, Flood M. Influence of timing of admission in labour and management of labour on method of birth: results from a randomised controlled trial of caseload midwifery (COSMOS trial). Midwifery. 2013;29(12):1297-302. https://doi.org/10.1016/j.midw.2013.05.014

15. Zadeh SN, Shafaie FS, Ghojazadeh M. The effects of early admission of pregnant women during latent phase on pregnant outcomes in tabriz taleghani hospital. Int J Women's Health Reprod Sci[Internet]. 2014[cited 15 Aug 2020];2(4):254-9.Available from: https://www.sid.ir/ en/journal/ViewPaper.aspx?id=357023

16. Sanches NC, Mamede FV, Vivancos RBZ. The profile of women who have experienced cesarean section and obstetric care at a public maternity hospital in Ribeirao Preto. Texto Contexto Enferm. 2012;21(2):418-26. https://doi.org/10.1590/S0104-07072012000200021

17. lobst SE, Breman RB, Bingham D, Storr CL, Zhu S, Johantgen M. Associations among cervical dilatation at admission, intrapartum care, and birth mode in low-risk, nulliparous women. Birth. 2019;46(2):253-61. https://doi.org/10.1111/birt.12417

18. Leal MC, Pereira APE, Domingues RMM, Filha MMT, Dias MAB, Nakamura-Pereira M, et al. Obstetric interventions during labor and childbirth in Brazilian low-risk women. Cad Saude Publica. 2014;30(Suppl-1):S17-S32. https://doi.org/10.1590/0102-311X00151513

19. Organização Mundial de Saúde (OMS). Recomendações para o aumento do trabalho de parto. [Internet]. 2015 [cited 15 Aug 2020 ]. Available from:https://apps.who.int/iris/bitstream/handle/10665/174001/WHO_RHR_15.05_por.pdf?ua=1

20. Felisbino-Mendes MS, Santos LO, Amorim T, Costa IN, Martins EF. Does the use of pharmacological analgesia influence childbirth outcomes? Acta Paul Enferm. 2017;30(5):458-65. https://doi.org/1982-0194201700067

21. Fernandes RLV, Damasceno AKC, Herculano MMS, Martins RDST, Oriá MOB. Pharmacological obstetric analgesia: a study of obstetric and neonatal outcomes. Rev Rede Enferm Nord. 2017;18(5):687. https://doi.org/10.15253/2175-6783.2017000500017

22. Entringer AP, Pinto M, Dias MAB, Gomes MASM. Cost-effectiveness analysis of spontaneous vaginal delivery and elective cesarean for normal risk pregnant women in the Brazilian Unified National Health System. Cad Saude Publica. 2018;34(5):e00022517. https://doi. org/10.1590/0102-311x00022517

23. Ministério da Saúde (BR). Diretrizes de Atenção à Gestante: a operação Cesariana. Conitec. Brasília: Ministério da Saúde [Internet]. 2016 [cited 15 Aug 2020]. Available from: http://conitec.gov.br/images/Relatorios/2016/Relatorio_Diretrizes-Cesariana_final.pdf

24. Ministério da Saúde (BR). Secretaria de Políticas de Saúde. Parto, aborto e puerpério: assistência humanizada à mulher. Brasília: Ministério da Saúde [Internet]. 2001 [cited 15 Aug 2020]. Available from: https://bvsms.saude.gov.br/bvs/publicacoes/cd04_13.pdf

25. World Health Organization (WHO). Intrapartum care for a positive childbirth experience.Geneva: World Health Organization [Internet]. 2018[cited 15 Aug 2020]. Available from: http://apps.who.int/iris/bitstream/10665/260178/1/9789241550215- eng.pdf?ua=1\%0Ahttp:// www.who.int/reproductivehealth/publications/intrapartum-care-guidelines/en/

26. Monguilhott JJC, Brüggemann OM, Freitas PF, D'Orsi E. Nascer no Brasil: a presença do acompanhante favorece a aplicação das boas práticas na atenção ao parto na região Sul. Rev Saúde Pública. 2018;52. https://doi.org/10.11606/s1518-8787.2018052006258

27. Nilsen $\mathrm{E}$, Sabatino $\mathrm{H}$, Lopes MH. The pain and behavior of women during labor and the different positions for childbirth. Rev Esc Enferm USP. 2011;45(3):557-65. https://doi.org/10.1590/S0080-62342011000300002

28. Cagnin ERG, Mamede MV, Mamede FV. Qualified care to labor : a descriptive study. Rev Enferm UFPE. 2014;8(10):3266-74. https://doi. org/10.5205/1981-8963-v8i10a10056p3266-3274-2014

29. Reis TR, Zamberlan C, Quadros JS, Grasel JT, Moro ASS. Obstetric Nurses: contributions to the objectives of the Millennium Development Goals. Rev Gaúcha Enferm. 2015;36(spe):94-101. https://doi.org/10.1590/1983-1447.2015.esp.57393

30. Caus ECM, Santos EKA, Nassif AA, Monticelli M. The process of giving birth assisted by obstetrician nurse in a hospital context: mean for the parturients. Esc Anna Nery. 2012;16(1):34-40. https://doi.org/10.1590/S1414-81452012000100005 